\title{
GI for Public Health
}

Stefan Kienberger and Michael Hagenlocher (Eds.) 